\title{
STUDI EVALUASI PASCATAMBANG PT. RATU SAMBAN MINING KABUPATEN BENGKULU TENGAH PROVINSI BENGKULU
}

\author{
Arief Huzeini ${ }^{1}{ }^{\text {}}$, Hery Suhartoyo ${ }^{2}$, Agus Susatya ${ }^{2}$ \\ ${ }^{1)}$ PT. Ratu Samban Mining Kota Bengkulu \\ ${ }^{2)}$ Jurusan Kehutanan Fakultas Pertanian Universitas Bengkulu
}

\begin{abstract}
ABSTRAK
PT. Ratu Samban Mining adalah sebuah perusahaan yang bergerak di bidang pertambangan Batubara dengan luas izin Operasi Produksi seluas 1.955.06 Ha, secara administratif terletak di desa Renah Kandis Kecamatan Pagar Jati, daerah Sekayun Kecamatan Bang Haji, Desa Air Kotok dan Desa Batu Beriang Kecamatan Pematang Tiga Kabupaten Bengkulu Tengah, Provinsi Bengkulu. Pada suatu saat industri pertambangan akan berakhir atau ditutup, baik dikarenakan sumber daya alam habis maupun hal-hal yang menyebabkan industri pertambangan tersebut berhenti sehingga pada saat kegiatan pertambangan tersebut berhenti atau ditutup, maka akan timbul permasalahan-permasalahan, antara lain terganggunya fungsi lingkungan hidup. Oleh sebab itu tujuan dari penelitian ini adalah memberikan gambaran kondisi akhir pasca operasional penambangan, melakukan evaluasi kinerja PT. Ratu Samban Mining serta memberikan rekomendasi pascatambang. Metode analisis data yang digunakan adalah metode desk study dengan data-data utamanya adalah Permen ESDM Nomor 7 Tahun 2014. Hasil evaluasi pascatambang PT. Ratu Samban Mining Berdasarkan Permen ESDM Nomor 7 Tahun 2014 didapatkan bahwa pelaksanaan pascatambang yang telah direalisasikan mendapatkan nilai $28,57 \%$. Hal ini berarti bernilai Jelek. Untuk pengembalian Izin usaha Pertambangan (IUP) ke Menteri, gubernur, atau bupati/ walikota berdasarkan ketentuan peraturan perundang-undangan berlaku, maka program pascatambang dapat dilaksanakan kembali masa perbaikannya selama 5 tahun, sehingga program pascatambang dapat mencapai nilai yang memadai yaitu $>80$.
\end{abstract}

Kata Kunci : ratu samban mining, pascatambang, reklamai

\section{PENDAHULUAN}

\begin{abstract}
Merujuk pada definisi yang tertuang dalam UU No 4 tahun 2009 tentang Pertambangan Mineral dan Batubara, pascatambang diartikan sebagai kegiatan setelah akhir sebagian atau seluruh kegiatan usaha pertambangan untuk memulihkan fungsi lingkungan dan fungsi sosial. Untuk mewujudkan pembangunan berkelanjutan, kegiatan usaha pertambangan harus dilaksanakan dengan memperhatikan prinsip lingkungan hidup, transparansi dan partisipasi masyarakat. Prinsip pengelolaan lingkungan hidup meliputi perlindungan
\end{abstract}

terhadap kualitas air permukaan, air tanah, air laut, dan udara sesuai dengan standar baku mutu lingkungan hidup dan ketentuan peraturan perundang-undangan.

Reklamasi adalah usaha memperbaiki (memulihkan kembali) lahan yang rusak sebagai akibat kegiatan usaha pertambangan, agar dapat berfungsi secara optimal sesuai dengan kemampuannya (Latifah, 2003). Penanganan tanah zona pengakaran perlu dilakukan pada waktu pengupasan tanah penutup pada saat memulai kegiatan penambangan. Tanah penutup dikupas, dipindahkan dan 
ditimbun disekitar area pit yang dibuka hal ini dilakukan untuk digunakan untuk menimbun kembali lahan bekas tambang tersebut.

Sembiring (2008) mengemukakan bahwa areal bekas tambang yang belum direvegetasi mempengaruhi kemampuan tanah dalam menahan erosi, pukulan air hujan yang langsung ke permukaan tanah menyebabkan butir-butir tanah akan hancur dan selanjutnya akan menutupi pori-pori tanah dan membuat tanah menjadi padat.

Bioremediasi/ Fitoremediasi lahan pascatambang batubara, bioremediasi adalah suatu proses pemulihan polutan dengan memanfaatkan jasa makhluk hidup seperti mikroba (bakteri, fungi, khamir), tumbuhan hijau atau enzim yang dihasilkan dalam proses metabolisme mereka (Widyati, 2008).

Berdasarkan Peraturan Menteri ESDM Nomor 7 tahun 2014 Rencana Penutupan Tambang di bagi menjadi dua bagian yaitu rencana pascatambang dan rencana reklamasi tambang. Rencana pascatambang ini wajib dibuat oleh perusahaan dan menjadi prasyarat dikeluarkannya IUP/IUPK Operasi Produksi sebagaimana diatur dalam UU No. 4 Tahun 2009 Pasal 99 Ayat 1. Setiap pemegang IUP dan IUPK wajib menyerahkan rencana reklamasi dan rencana pascatambang pada saat mengajukan permohonan IUP Operasi Produksi atau IUPK Operasi Produksi.

\section{Pada Peraturan Menteri ESDM} Nomor 7 Tahun 2014, kewajiban melakukan monitoring dan evaluasi dilakukan sebagai syarat pencairan dana jaminan reklamasi, yang dijelaskan pada pasal 46, 51, 57 dan 60-62. Evaluasi keberhasilan pascatambang mempunyai kriteria-kriteria yang dapat menjadi aspek dasar penilaian sebagaimana yang tertuang di Peraturan Menteri ESDM Nomor 7 Tahun 2014, pertimbangan didalam pembobotan penilaian pascatambang.
Pada saat kegiatan pertambangan tersebut berhenti atau ditutup, maka akan timbul permasalahan-permasalahan, antara lain terganggunya fungsi lingkungan hidup serta turunnya kualitas sosial dan kesehatan masyarakat. Oleh sebab itu sangatlah diperlukan perencanaan penutupan tambang dalam rangka upaya menanggulangi permasalahanpermasalahan tersebut untuk menjamin pemanfaatan lahan di wilayah bekas kegiatan pertambangan agar berfungsi sesuai peruntukannya.

Memang kenyataannya kegiatan pertambangan akan memberi dampak baik dampak negatif maupun dampak positif. Dampak positif yang diterima mungkin tidak akan lebih besar dibandingkan dampak negatif yang timbul pasca operasi tambang. Kegiatan pertambangan tidak akan pernah terlepas dari persoalan lingkungan hidup. Indonesia merupakan salah satu negara di dunia yang mengalami kerusakan lingkungan serius akibat kegiatan pertambangan.

Perubahan kondisi lingkungan yang terjadi di lokasi tambang dan sekitarnya merupakan konsekuensi dari proses kegiatan penambangan. Maraknya pembukaan lahan pertambangan nampaknya tidak dibarengi dengan kesadaran akan dampak yang ditimbulkan terhadap lingkungan.

Kerusakan lingkungan yang ditimbulkan sebagai dampak negatif dari kegiatan pertambangan adalah banyaknya lahan tambang yang termasuk dalam IUP yang rusak pasca kegiatan penambangan. Menurut Setiawaty (2012), sektor pertambangan merupakan salah satu sektor kegiatan ekonomi yang di samping kegiatannya menghasilkan produksi hasil tambang, juga menimbulkan dampak kerusakan lahan dan bentang alam yang sifatnya sukar dikembalikan ke bentuk semula (irreversible).

Adanya konsep green mining diharapkan akan menciptakan hubungan yang seimbang antara perusahaan pelaku 
penambangan, masyarakat dan alam (Yin dkk., 2009). Namun demikian, seperti yang dikemukakan oleh Dong-sheng dkk. (2009), sangat sulit membuat pilihan antara eksploitasi sumber daya dan perlindungan lingkungan ekologi. Perlu dicarikan cara untuk menyelesaikan kontradiksi antara teori dan yang terjadi dilapangan.

Kegiatan penambangan dapat menimbulkan kerusakan, karena sekali suatu daerah dibuka untuk operasi pertambangan, maka daerah tersebut akan berpotensi menjadi rusak. Dalam rangka mengembalikan kondisi tanah sedemikian rupa sehingga dapat berfungsi dan berdaya guna sesuai peruntukannya, maka terhadap lahan bekas pertambangan, selain dilakukan penutupan tambang juga harus dilakukan pemulihan kawasan bekas pertambangan. Oleh sebab itu tujuan dari penelitian ini adalah: 1). Memberikan gambaran kondisi akhir pasca operasional penambangan, 2). . Melakukan evaluasi kinerja PT. Ratu Samban Mining, 3). Memberikan rekomendasi pascatambang.

\section{METODE PENELITIAN}

Penelitian ini dilakukan pada bulan Mei 2018- Juli 2018, lokasi penelitian secara administratif, berada di lokasi Izin Usaha Pertambangan Operasi Produksi PT. Ratu Samban Mining KW.BT.011-011 terletak di dan desa Renah Kandis Kecamatan Pagar Jati, daerah Sekayun Kecamatan Bang Haji, Desa Air Kotok dan Desa Batu Beriang Kecamatan Pematang Tiga Kabupaten Bengkulu Tengah, Provinsi Bengkulu (Gambar 1).

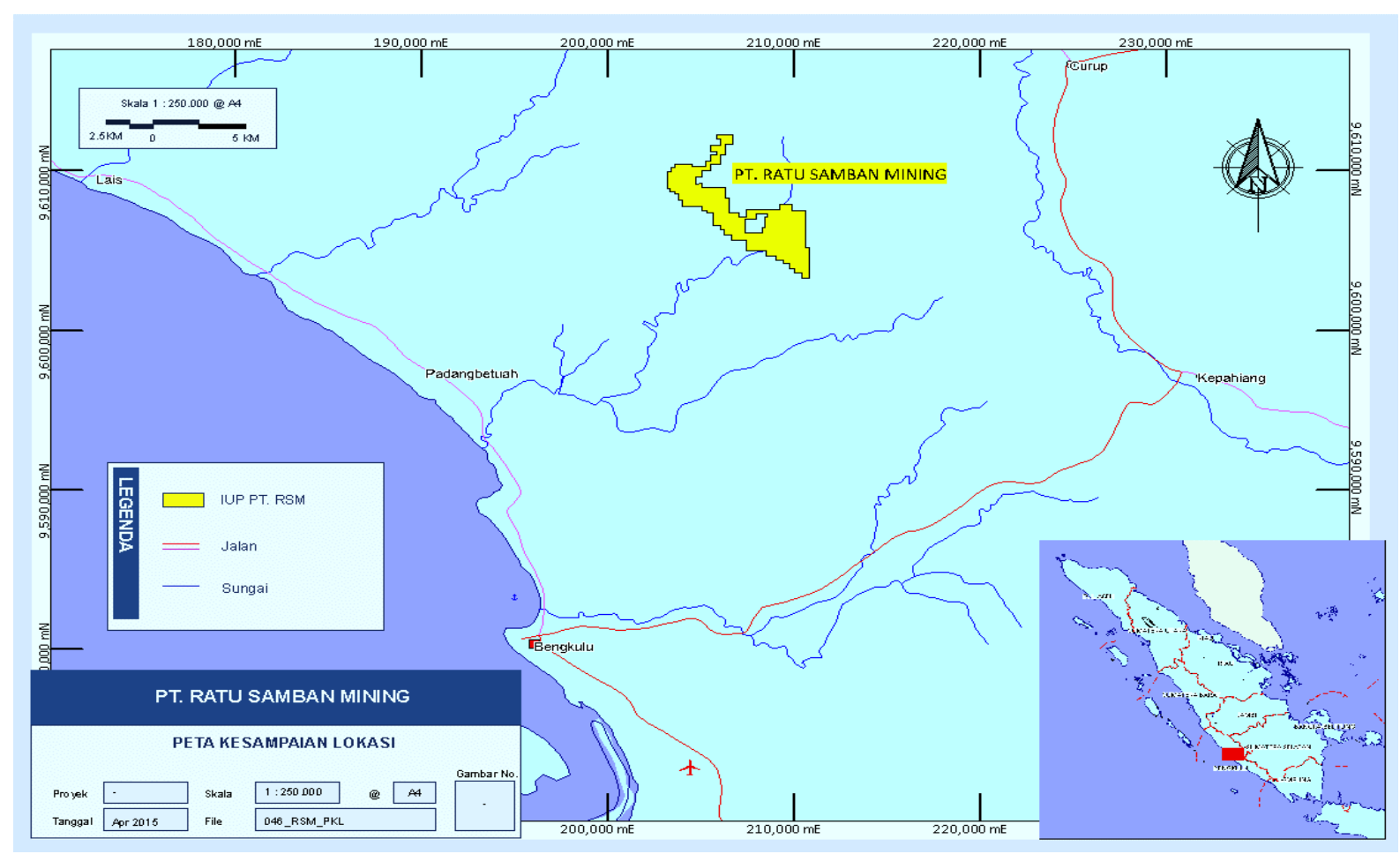

Gambar 1. Peta Lokasi Kesampaian daerah.

Metode analisis data yang digunakan adalah metode desk study dengan data-data utamanya adalah Permen ESDM Nomor 7 Tahun 2014, data rencana penambangan, dokumen pascatambang dan gambaran rona akhir kegiatan penambangan. Kondisi akhir pasca operasional yang tertuang dalam laporan telah diamati langsung melalui 
pengamatan lapangan yang disesuaikan dengan dokumen pascatambang untuk selanjutnya diberikan skoring berdasarkan luasan yang telah dilakukan pembongkaran, penataan, reklamasi, pengendalian dan pemulihan. Selanjutnya dilakukan penyesuaian dengan kriteria keberhasilan Permen ESDM Nomor 7 Tahun 2014 sebagai dasar penilaian untuk dilakukan pembobotan berdasarkan jumlah area yang direalisasikan, dari hasil penilaian yang telah disesuaikan dengan Permen ESDM didapatkan kesimpulan akhir penelitian, setelah mendapatkan kesimpulan akhir maka penulis memberikan Rekomendasi pascatambang.

\section{Persiapan Peralatan}

Alat yang digunakan dalam penelitian ini adalah Garmin GPSmap62s digunakan untuk penentuan titik lokasi dan pengecekan luasan, Camera Digital untuk dokumentasi kegiatan di lapangan. Untuk kepentingan analisis citra digunakan antara lain perangkat komputer dengan perangkat lunak software SASPlanet, Software Arcgis 10.1, dan peralatan survey lainnya seperti kompas Shuntoo untuk pengecekan arah dan sudut kemiringan.

Tahapan Pengumpulan Data

Studi Literatur

Studi literatur dilakukan pada saat sebelum dan sesudah penelitian dilakukan. Literatur yang digunakan berasal dari dokumen Rencana Penambangan dan laporanlaporan yang berhubungan dengan penelitian ini.

Pengambilan Data

a. Data Primer
1. Data wilayah rona awal Pascatambang.

2. Data bukaan lahan untuk tapak proyek dan wilayah yang tertambang.

3. Data tahapan program reklamasi yang akan dilaksanakan.

4. Data tahapan program pemeliharaan dan perawatan tapak bekas tambang yang akan dilaksanakan.

b. Data sekunder

1. Literatur- literatur yang berhubungan dengan Reklamasi dan Pascatambang.

2. Peraturan Menteri Energi dan Sumber Daya Mineral Nomor 07 Tahun 2014.

3. Peta Geologi Regional Kabupaten Bengkulu Tengah.

4. Peta Rona Awal PT. Ratu Samban Mining.

\section{HASIL DAN PEMBAHASAN}

Kegiatan Pascatambang PT. Ratu Samban Mining berdasarkan Permen ESDM Nomor 7 Tahun 2014 tentang pascatambang, dengan kegiatan sebagai berikut : PT. Ratu Samban Mining memiliki tiga akses jembatan hanya satu jembatan yang telah dibongkar dua jembatan lainnya dijadikan akses untuk fasilitas umum, adapun fasilitas lain seperti pos jaga sudah dilakukan pembongkaran.

Standar keberhasilan pembongkaran fasilitas tambang telah tertuang dalam dokumen pascatambang adalah dengan tidak ditemukan lagi puing-puing dan pondasi yang belum terbongkar. Rencana pembongkaran fasilitas tambang tersebut sebesar $264 \mathrm{~m}^{2}$ tetapi realisasinya sebesar $84 \mathrm{~m}^{2}$. Hasil penilaian kriteria keberhasilan berdasarkan permen ESDM Nomor 7 Tahun 2014 adalah 31,82 \% (Gambar 2). 


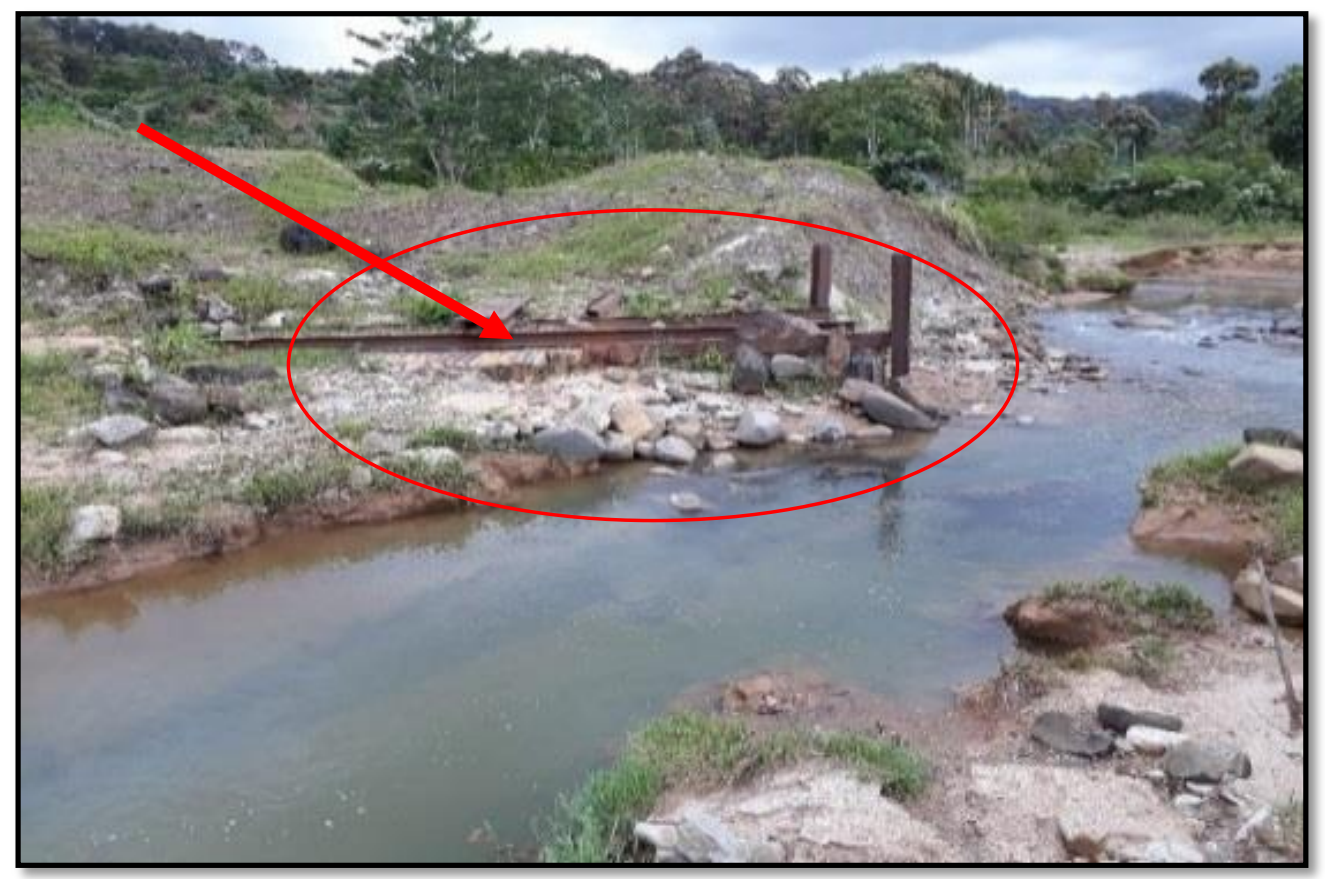

Gambar 2. Akses Jembatan di Blok III \& Pos Jaga.

Pada area kolam sedimen seluruhnya sudah dilakukan pembongkaran dengan tidak ditemukan lagi tanggul kolam sedimen serta tidak ditemukan adanya air yang tergenang. Standar keberhasilan pembongkaran fasilitas pengolahan dan/pemurnian telah tertuang dalam dokumen pascatambang, sedangkan area settling pond PT. Ratu Samban Mining belum dilakukan pem- bongkaran dan penataan sehingga masih ditemukan kolam yang belum di bongkar dan ditata. Rencana pembongkaran fasilitas tambang tersebut sebesar 5,329.8 m2 tetapi realisasinya sebesar 29,8 m2. Hasil penilaian kriteria keberhasilan berdasarkan permen ESDM Nomor 7 Tahun 2014 adalah $0,56 \%$ (Gambar 3).

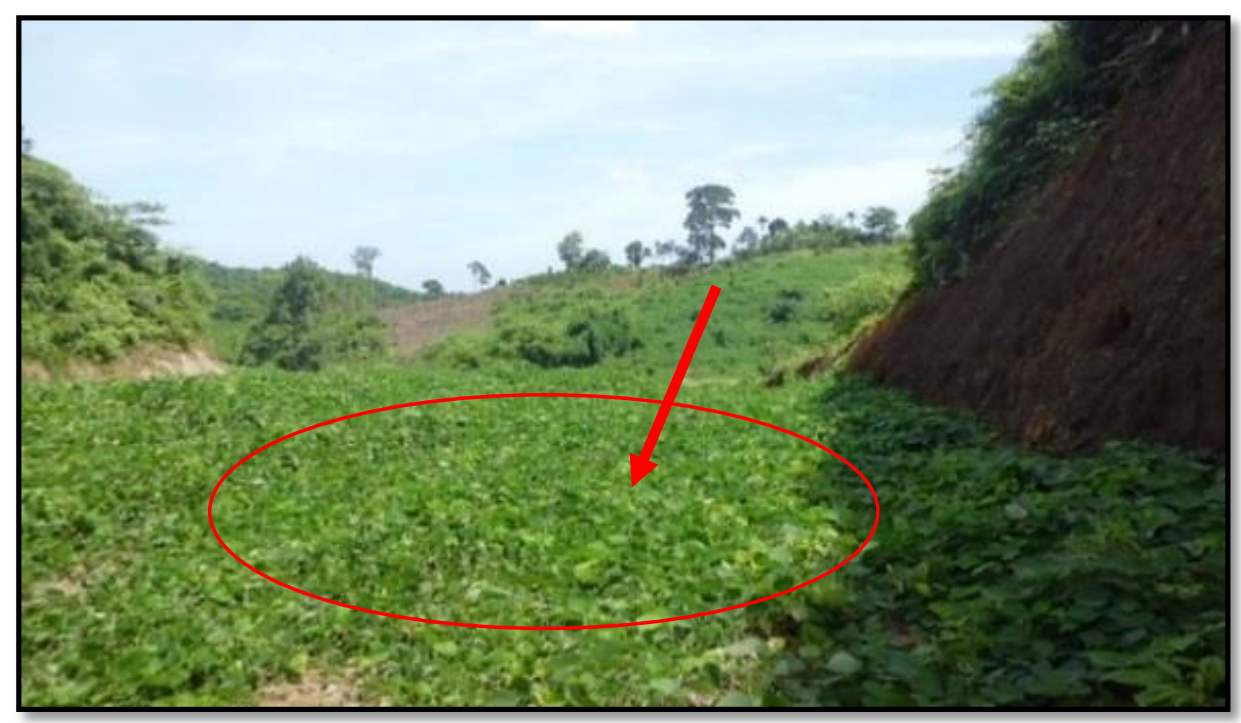

Gambar 3. Settling Pond Pit F \& Pit B1-2. 
Berdasarkan pengamatan pada area fasilitas penunjang PT. Ratu Samban Mining ada beberapa fasilitas penunjang sudah dilakukan pembongkaran, dan juga masih ada yang belum dilakukan pembongkaran disebabkan masih bisa dipergunakan untuk fasilitas umum. Fasilitas penunjang PT. Ratu Samban Mining diserahkan ke pemerintah melalui pemda kabupaten atau dinas terkait kemudian selanjutnya dikem- balikan ke masyarakat sesuai dengan amanat undang-undang mineral dan batubara nomor 4 tahun 2009 pasal 12 dan peraturan pemerintah nomor 32 tahun 1969 pasal 43. Rencana pembongkaran fasilitas penunjang tambang tersebut sebesar $320.424 \mathrm{~m}^{2}$ tetapi realisasinya sebesar 227 $\mathrm{m}^{2}$. Hasil penilaian kriteria keberhasilan berdasarkan permen ESDM Nomor $7 \mathrm{Ta}$ hun 2014 adalah $0,07 \%$.

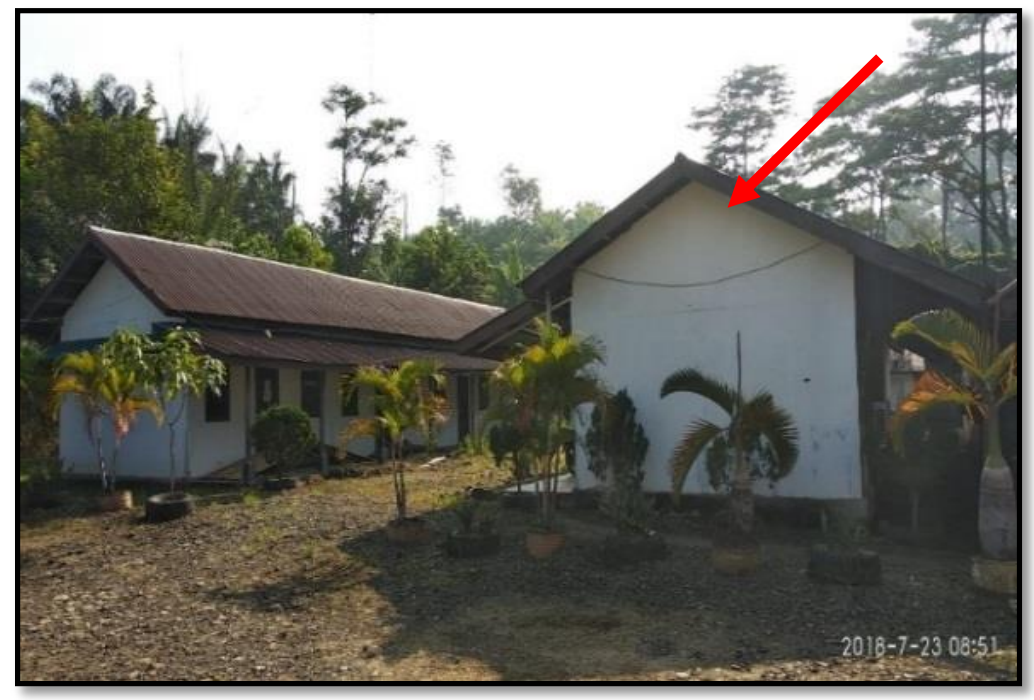

Gambar 4. Bangunan Fasilitas Tambang.

Pada area dumping dan stockpile, hampir seluruhnya belum dilakukan reklamasi dikarnakan saat terhentinya kegiatan penambangan, perusahaan di demo oleh masyarakat sehingga saat ini masih ditemukan area yang belum direklamasi dan masih kritis serta sebagian lahan ada yang mengalami erosi. Rencana reklamasi lahan bekas fasilitas tambang tersebut sebesar $141.500 \mathrm{~m}^{2}$ tetapi realisasinya sebesar $31.300 \mathrm{~m}^{2}$. Hasil penilaian kriteria keberhasilan berdasarkan permen ESDM Nomor 7 Tahun 2014 adalah 22,12\%.

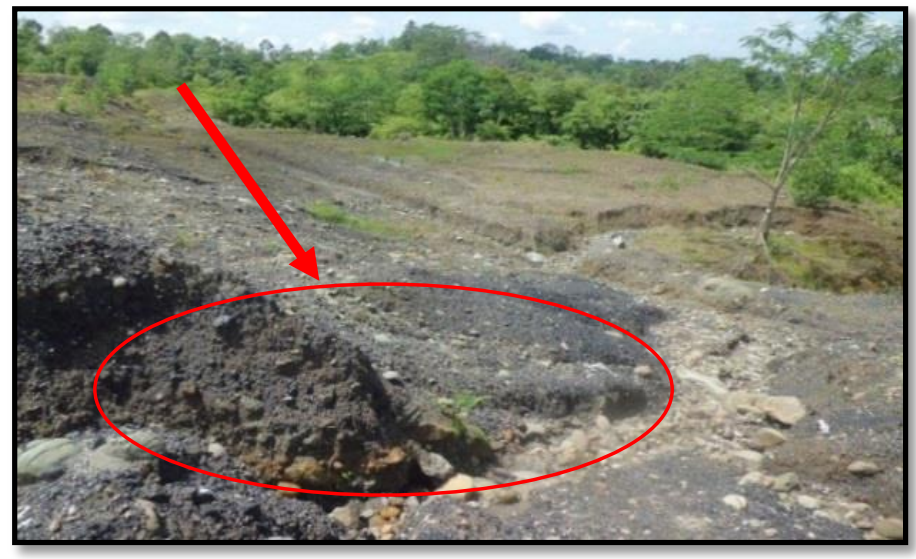

Gambar 5. ROM Stockpile di Batu Beriang. 
Sejalan dengan penutupan PIT area maka kolam pengolahan sedimen di timbun kembali dan diratakan serta dilakukan revegetasi, pada area kolam sedimen PT. Ratu Samban Mining seluruhnya sudah dilakukan reklamasi sehingga tidak ditemukan area yang belum direklamasi standar keberhasilan keberhasilan reklamasi tertuang dalam dokumen rencana pascatambang. Untuk kolam settling pond belum sama sekali dilakukan reklamasi masih ditemukan genangan air dan tanggul, rencana reklamasi lahan bekas fasilitas pengolahan tambang tersebut sebesar 5.329,8 $\mathrm{m} 2$ tetapi realisasinya sebesar 29,8 m2. Hasil penilaian kriteria keberhasilan berdasarkan permen ESDM Nomor 7 Tahun 2014 adalah $0.56 \%$.

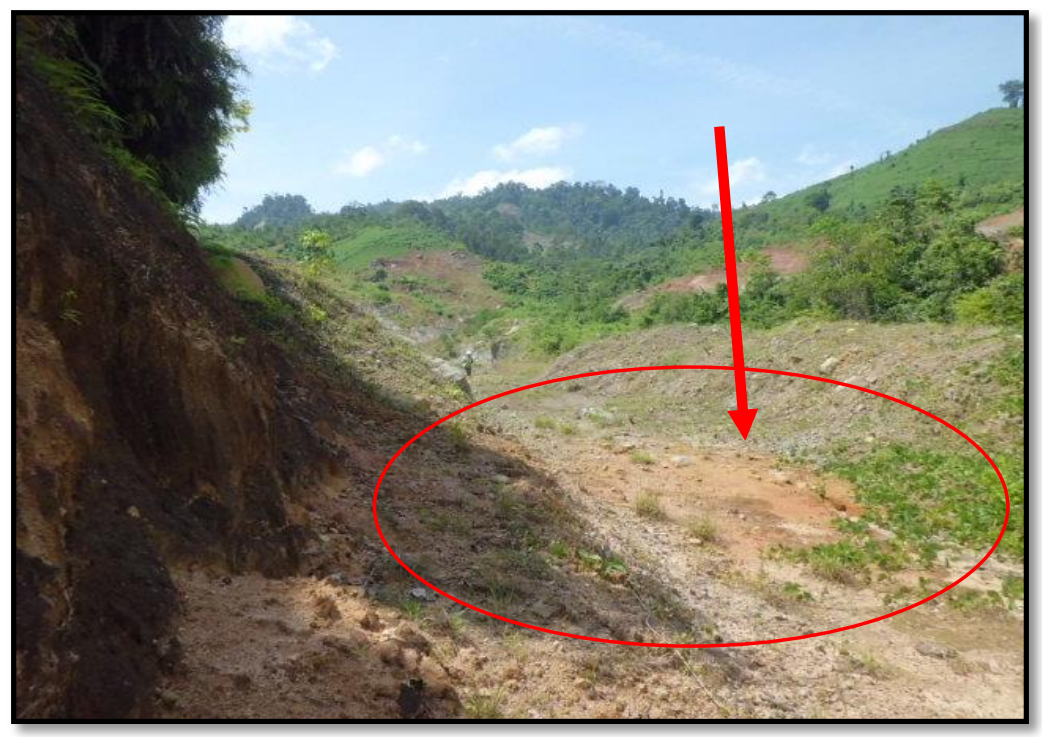

Gambar 6. Settling Pond Blok II pit 5

Berdasarkan pengamatan pada area fasilitas penunjang PT. Ratu Samban Mining ada beberapa fasilitas penunjang sudah direklamasi, dan juga masih ada yang belum dilakukan reklamasi dikarnakan fasilitas tersebut masih bisa dipergunakan untuk kepentingan umum pertimbangan ini dengan alasan fasilitas tersebut berada didekat pemukiman masyarakat, fasilitas ini selanjutnya di serahkankan ke pemerintah melalui pemda kabupaten atau dinas terkait kemudian selanjutnya diserahkan ke masyarakat sesuai dengan amanat Undang-undang Mineral dan Batubara Nomor 4 Tahun 2009 pasal 12 dan Peraturan Pemerintah Nomor 32 Tahun 1969 pasal 43. Rencana pembongkaran fasilitas penunjang tambang tersebut sebesar $320.424 \mathrm{~m}^{2}$ tetapi realisasinya sebesar
$227 \mathrm{~m}^{2}$. Hasil penilaian kriteria keberhasilan berdasarkan permen ESDM Nomor 7 Tahun 2014 adalah 0,07 \%.

Daerah penambangan PT. Ratu Samban Mining ini tidak mempunyai indikasi Air Asam Tambang (AAT) sehingga tidak ada pengamanan atau penanganan khusus. Rencana pengamanan lahan bekas fasilitas tambang tersebut sebesar 141.500 $\mathrm{m}^{2}$ tetapi realisasi pengamanan atau penanganannya sebesar (nihil) $\mathrm{m}^{2}$. Hasil penilaian kriteria keberhasilan berdasarkan permen ESDM Nomor 7 Tahun 2014 adalah $0 \%$.

Kolam sedimen PT. Ratu Samban Mining pada tahap pascatambang ini selalu dipantau dan di cek pH air nya oleh UPTD Laboratorium Lingkungan Pemerintah Kota Bengkulu Dinas Lingkungan Hidup 
dengan Sertifikasi Hasil Uji Nomor: 445/004/UPTD-LH Kota BKL/2018 dengan hasil analisa $\mathrm{pH}$ air 7,10. Rencana pemulihan lahan bekas fasilitas tambang tersebut sebesar $5.329,8 \mathrm{~m} 2$ dan terealisasi sebesar 5.329,8 m2. Hasil penilaian kriteria keberhasilan berdasarkan permen ESDM Nomor 7 Tahun 2014 adalah $100 \%$.

PT. Ratu Samban Mining belum melaksanakan tes uji lab untuk area lokasi berpotensi terkontaminasi di area fasilitas penunjang, sehingga belum ada pemulihan tanah pada area yang berpotensi terkontaminasi, namun PT. Ratu Samban Mining melaksanakan pencegahan dengan

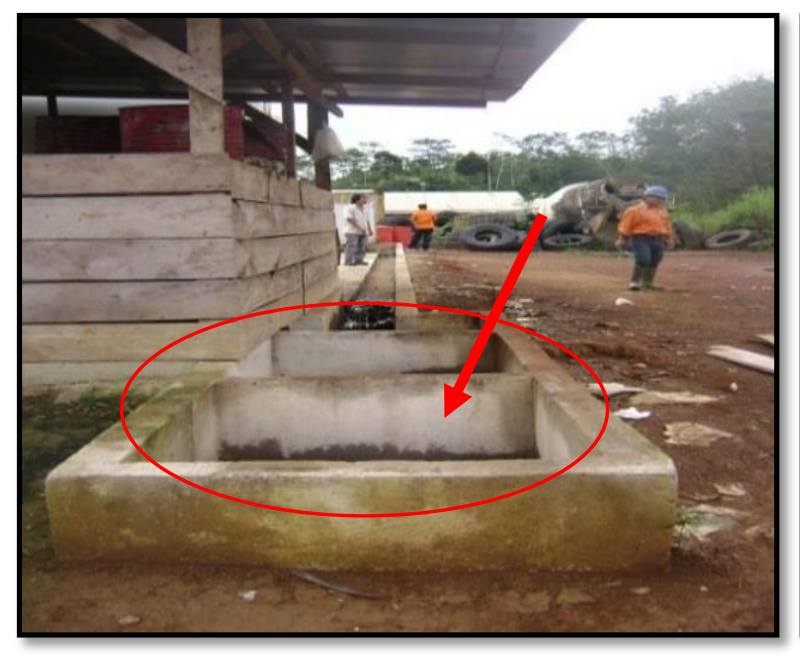

(a) pembuatan Oil Trap di TPS B3, menyediakan bak penampungan LB3.

Daerah penambangan PT. Ratu Samban Mining ini berada jauh dari tempat pengisian BBM, bangunan Bengkel ataupun TPS B3, bangunan nya dibuat permanen dengan beton agar limbah tersebut tidak terkontaminasi langsung dengan tanah. Rencana pengamanan lahan bekas fasilitas tambang tersebut sebesar $672 \mathrm{~m} 2$ tetapi realisasinya sebesar $572 \mathrm{~m} 2$. Hasil penilaian kriteria keberhasilan berdasarkan permen ESDM Nomor 7 Tahun 2014 adalah $85.12 \%$.

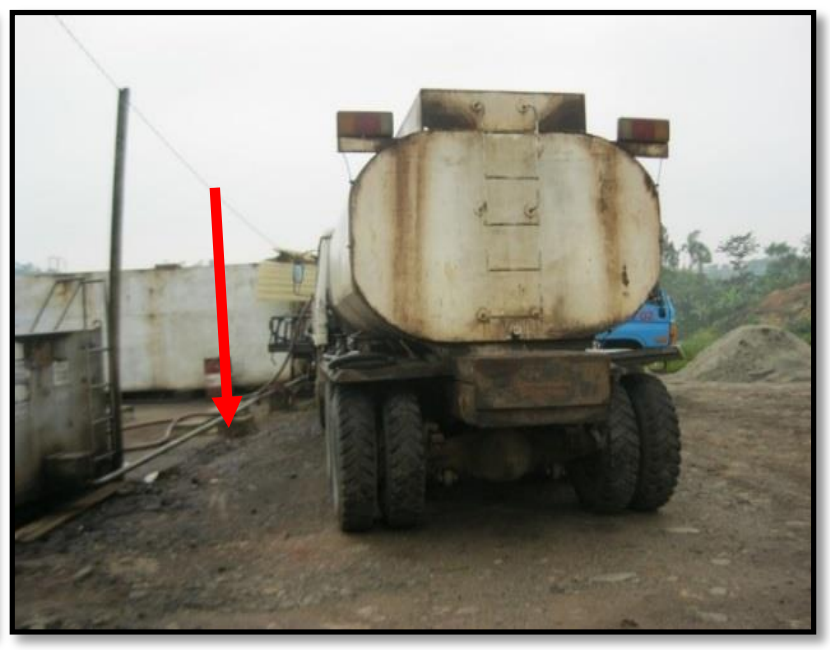

(b)

Gambar 7 (a). Plow Chort Alur Oil Trap di TPS B3 dan (b).Lahan Rawan Terkontaminasi LB3/ Hidrocarbon.

Sesuai dengan Permen ESDM Nomor 7 Tahun 2014 tentang pelaksanaan reklamasi dan pascatambang pada kegiatan usaha pertambangan mineral dan batubara Setelah dilakukan evaluasi berdasarkan kriteria dan indikator keberhasilan reklamasi dan pascatambang dengan dasar Per- men ESDM Nomor 7 Tahun 2014 tentang pelaksanaan reklamasi dan pascatambang maka dapat dilakukan penilaian keberhasilan pascatambang pada lahan bekas tambang batubara PT. Ratu Samban Mining. Penilaian keberhasilan pascatambang dapat dilihat pada Tabel 1. 
Tabel 1. Penilaian Pascatambang PT. Ratu Samban Mining berdasarkan Peraturan Menteri ESDM Nomor 7 Tahun 2014.

\begin{tabular}{|c|c|c|c|c|}
\hline No & Uraian Kegiatan & Bobot & $\begin{array}{c}\text { Bobot Evaluasi } \\
(\%)\end{array}$ & $\begin{array}{l}\text { Hasil Penilaian } \\
\qquad(\%)\end{array}$ \\
\hline \multirow[t]{4}{*}{1.} & Tapak Bekas Tambang : & (30) & & \\
\hline & Pembongkaran & 5 & 31,82 & 1,591 \\
\hline & Reklamasi & 15 & 22,12 & 3,318 \\
\hline & $\begin{array}{l}\text { Pengamanan semua lahan } \\
\text { bekas tambang yang } \\
\text { berpotensi bahaya }\end{array}$ & 10 & 0 & 0 \\
\hline \multirow[t]{4}{*}{2.} & $\begin{array}{l}\text { Fasilitas Pengolahan } \\
\text { dan/atau pemurnian : }\end{array}$ & (40) & & \\
\hline & Pembongkaran & 10 & 0,56 & 0,056 \\
\hline & Reklamasi & 15 & 0,56 & 0,084 \\
\hline & $\begin{array}{l}\text { Pemulihan (remediasi) tanah } \\
\text { yang terkontaminasi }\end{array}$ & 15 & 100 & 15 \\
\hline \multirow[t]{5}{*}{3.} & Fasilitas Penunjang : & (30) & & \\
\hline & Pembongkaran & 5 & 0,07 & 0,003 \\
\hline & Reklamasi & 15 & 0,07 & 0,010 \\
\hline & $\begin{array}{l}\text { Pemulihan (remediasi) tanah } \\
\text { yang terkontaminasi }\end{array}$ & 10 & 85,12 & 8,512 \\
\hline & Total & $10 \%$ & & $28,57 \%$ \\
\hline
\end{tabular}

Sumber (Source) : Pengamatan di PT. Ratu Samban Mining, 2018.

Evaluasi Pascatambang PT. Ratu Samban Mining dilakukan penilaian Berdasarkan Permen ESDM Nomor 7 Tahun 2014 tentang pelaksanaan reklamasi dan pascatambang usaha pertambangan mineral dan batubara. Berdasarkan penilaian pada tiap kriteria yang telah dilakukan pada penelitian didapatkan bahwa pelaksanaan pascatambang yang telah direalisasikan mendapatkan nilai $28,57 \%$. Hal ini berarti bernilai Jelek (hasil program pascatambang tidak dapat diterima dan diperlukan perbaikan yang intensif).

Tabel 2. Keterangan Kriteria Penilaian Pascatambang.

\begin{tabular}{|c|c|c|}
\hline No & Total Nilai & Keterangan \\
\hline & Total nilai $>80$ & $\begin{array}{l}\text { Baik (hasil pelaksanaan program pascatambang } \\
\text { dapat diterima). }\end{array}$ \\
\hline 2. & Total nilai $60-80$ & $\begin{array}{l}\text { Sedang (hasil pelaksanaan program pascatambang } \\
\text { diterima dengan catatan perlu dilakukan perbaikan } \\
\text { sampai mencapai nilai }>80 \text {.) }\end{array}$ \\
\hline & Total nilai $<60$ & $\begin{array}{l}\text { Jelek (hasil program pascatambang tidak dapat } \\
\text { diterima dan diperlukan perbaikan yag intensif). } \\
\text { Untuk pengembalian Izin usaha pertambangan } \\
\text { (IUP) ke Menteri, Gubernur, atau Bupati/ Walikota } \\
\text { sesuai kewenangan berdasarkan ketentuan } \\
\text { peraturan perundang-undangan berlaku, apabila } \\
\text { izinnya sudah habis, maka program pascatambang } \\
\text { dapat dilaksanakan kembali masa perbaikannya } \\
\text { selama } 5 \text { tahun, sehingga program pascatambang } \\
\text { dapat mencapai nilai yang memadai yaitu }>80 \text {. }\end{array}$ \\
\hline
\end{tabular}




\section{KESIMPULAN}

Ada beberapa faktor yang mengakibatkan ketidak efektifan pascatambang tersebut. Ada beberapa faktor yang mengakibatkan ketidak efektifan pascatambang tersebut. Secara ringkas gambaran kondisi akhir pasca operasional penambangan di wilayah PT. Ratu Samban Mining seperti tapak bekas tambang dimana akses jembatan 25\% sudah dilakukan pembongkaran dan pos jaga sudah dibongkar $100 \%$. Pada area dumping serta stockpile seluruhnya belum di reklamasi. Untuk fasilitas pengolahan dan/atau pemurnian seperti settlingpond belum sama sekali dilakukan pembongkaran dan reklamasi tetapi untuk kolam sedimen pada blok II dan III sudah dilakukan pembongkaran dan reklamasi, ada beberapa fasilitas penunjang yang belum dilakukan pembongkaran antara lain tangki BBM, bangunan bengkel, mess karyawan, bangunan kantor tempat ibadah dan lainlain, terkusus untuk kegiatan remediasi lahan yang terkontaminasi ada beberapa area seperti tangki BBM belum dilakukan pengamanan dan pemulihan, sedangkan area bangunan bengkel dan TPS B3 sudah dilakukan pemulihan dan penanganan. Dari hasil evaluasi Pascatambang PT. Ratu Samban Mining Berdasarkan Permen ESDM Nomor 7 Tahun 2014 tentang pelaksanaan reklamasi dan pascatambang usaha pertambangan mineral dan batubara PT. Ratu Samban Mining didapatkan bahwa pelaksanaan pascatambang yang telah direalisasikan mendapatkan nilai 28,57 \% . Hal ini berarti bernilai Jelek (hasil program pascatambang tidak dapat diterima dan diperlukan perbaikan yang intensif).

\section{DAFTAR PUSTAKA}

Dong-sheng, Z., F. Gang-wei, M. Liqiang, W. An and L. Yu-de. 2009. Harmony of Large Scale Underground Mining and
Surface Ecological Environment Protection in Desert District. A Case Study in Shendong Mining Area, Northwest of China. Procedia Earth and Planetary Science. Vol.1 pp 1114-1120.

Kementerian Energi Sumber Daya Mineral. Peraturan Menteri Energi Sumber Daya Mineral Republik Indonesia Nomor 07 Tahun 2014 tentang Pelaksanaan Reklamasi dan Pascatambang pada Kegiatan Usaha Pertambangan Mineral dan Batubara. Jakarta

Latifah, S. 2003. Kegiatan Reklamasi Pada Lahan Pascatambang. http://repository.usu.ac.id/bitstrea m/123456789/920/1/hutan-siti1. pdf. diakses tanggal 16 September 2011.

Latifah, S. 2003. Kegiatan Reklamasi Lahan Pada Bekas Tambang. Program Ilmu Kehutanan, Jurusan Manajemen Hutan, USU.

Setiawaty P. and Susi. 2012. Valuasi Ekonomi Pertambangan Selaras Lingkungan Lestari. (Studi Kasus Pertambangan Emas Pongkor). Jurnal Green Growth dan Manajemen Lingkungan. Vol. 1.

Sembiring S. (2008) Sifat Kimia dan Fisik Tanah pada Areal Bekas Tambang Bauksit di Pulau Bintan, Riau, Balai Penelitian Kehutanan Aek Nauli.

Widyati, E. 2008. Pemanfaatan Bakteri Pereduksi Sulfat untuk Bioremediasi Tanah Bekas Tambang Batubara. Biodiversitas Vol. 8 (4). pp: 283-286.

Widyati, E. 2008. Peranan Mikroba Tanah pada Kegiatan Rehabilitasi Lahan Bekas Tambang. Info Hutan. Vol. V No. 2. pp: 151-160.

Yin, L. Ming, Z. Zhen-fang and M. Xing. 2009. Study on Incentive Mechanisms of Coal Green Mining. Procedia Earth and Planetary Science. Vol.1 pp 211-218. 